Article

\title{
Biopolymer-Reinforced Levee for Breach Development Retardation and Enhanced Erosion Control
}

\author{
Dongwoo Ko ${ }^{1}$ (I) and Joongu Kang ${ }^{2, *}$ \\ 1 School of Constructional Disaster Prevention, Kyungpook National University, Daegu 41566, Korea; \\ rhehddn84@gmail.com \\ 2 River Experiment Center, Korea Institute of Civil Engineering and Building Technology, Goyang 10223, Korea \\ * Correspondence: jgkang02@kict.re.kr; Tel.: +82-010-2003-0518
}

Received: 5 March 2020; Accepted: 7 April 2020; Published: 9 April 2020

\begin{abstract}
This study proposes an earthen levee reinforcement method with a new biopolymer-based material to prevent levee scour and breach. It is an eco-friendly method that can efficiently protect the levee slope as it enhances soil strength, even at a very low concentration of biopolymer, and has high resistance to surface runoff in addition to promoting vegetation growth. The function and effectiveness of this method were demonstrated through an overflow-based semi-scale experiment in a previous study. In this study, we examined the effect of biopolymer-mixed soil layer on levee stability against an overflow-induced breach. In these experiments, biopolymer-mixed soils were sprayed on the crest and land-side levee surface. Two full-scale tests were conducted (2.5-2.7 m high and $14 \mathrm{~m}$ wide on bottom). Case 1 (control case) consisted of bare sand without any treatment, while Case 2 consisted of a 1.0\% biopolymer-mixed soil sprayed on the crest and landside slope of the levee and turf put on it. By applying an image analysis technique, we analyzed the breach phenomenon and breach retardation effect of the levee treated with a biopolymer and covered with vegetation. In this experiment, the slope loss rate of Case 2 was retarded 1.5 to 2.3 times over time as compared to Case 1 . During the experiment, we observed that soil erosion followed through the narrow water channel formed by the stripped turfs. This means that the grasses did not root firmly enough to protect the surface. In this regard, although the experimental results may seem unsatisfactory, the biopolymer was found to help improve erosion retardation. In 2020, we will conduct more experiments with different compositions and concentrations of the biopolymer regardless of levee vegetation. With this research, we expect to confirm that the new technology of using biopolymer-treated soils is promising for solving the levee overflow breach problem.
\end{abstract}

Keywords: levee; levee reinforcement; biopolymer; erosion control; levee breach; levee breach retardation; flood protection

\section{Introduction}

Overflow, seepage, and piping due to abnormal flooding can damage levees alongside rivers. Levee breaching in inland areas not only damages the river structure, it also threatens human life and property. Therefore, special measures are needed to reduce the damage caused by levee breaches in areas with dense populations and infrastructure.

The reinforcement techniques to reduce levee seepage presented in the River Design Standard of Korea (2018) include the reduction of the hydraulic gradient of the levee, the cross-sectional enlargement of the levee to increase the stability of its slope, and the layering of a slope coating to prevent the seepage of precipitates or river water into the levee. Other techniques include the prevention of levee 
seepage and breaching by installing a cut-off wall on the foundation ground and the reduction of seepage pressure by lining the riverside surface with an impermeable material.

Vegetation reinforcement is another method to stabilize the soil levee slope by creating conditions conducive to vegetation growth using natural materials, such as coconut mat [1-3]. At the working level, vegetated levees are divided into two categories: (1) vegetation reinforcement of levee slopes using only vegetation, and (2) a combination of vegetation reinforcement and soil reinforcement, with erosion control materials such as a net or mat to enhance the erosion resistance of the levee slope until vegetation begins to thrive. The main advantages of a vegetated levee are its eco-friendly nature and aesthetic appeal, along with the creation of new ecosystems. Notably, the vegetation mat method is economical because it involves only the cost of the seeds and the mat. The drawbacks of vegetated levees, however, are that they are less durable than stone or other solid materials and remain vulnerable until the vegetation has fully bloomed [4].

Previous studies on levees can be grouped into three research trends: (1) investigations of the mechanism of overflow-induced levee breach and infiltration characteristics of different levee materials [5-12], (2) analysis of seepage and breach behaviors by inserting sensors into a levee [13-16], and (3) stability analysis of levees with different combinations of reinforcing materials [17,18].

This study explores the potential of a biopolymer-based levee slope reinforcement technology for enhancing levee resistance to erosion during surface runoff while functioning as an erosion control technique, much like a vegetated levee. Biopolymers are living polymers synthesized from microorganisms such as bacteria rather than synthetic polymers. Studies on biopolymers can be grouped into three trends: (1) analysis of biopolymer-soil interaction and investigation of the geotechnical engineering properties of mixed soils, (2) investigation of the reinforcement effects of various biopolymers mixed with soil, and (3) verification of slope reinforcement and erosion control effects of biopolymer-soil mixtures [19-21]. Biopolymers have also demonstrated ecological qualities and aesthetics as well as their effect in promoting vegetation growth and enhancing erosion resistance [22].

The Andong River Experiment Center (REC) of the Korea Institute of Civil Engineering and Building Technology (KICT) performed a full-scale test to verify the effect of biopolymer-mixed soil layers on the stability of levees in overflow conditions. The biopolymers used in this study were polysaccharides that have been shown to have no adverse effects on local ecosystems. In the experimental setup, a practical overflow-induced levee breach was emulated under two conditions: in Case 1 the sand levee was not treated with biopolymer, and Case 2 consisted of biopolymer-soil mixture cover and vegetation survival. The biopolymer-soil mixture was sprayed on the levee crown and inland-side levee slope. Upon completion of the experiment, pixel-based image analysis was performed to capture the levee breach events under the experimental conditions. The breach retardation effect was analyzed quantitatively, and the results were presented.

\section{Significance of the Study}

Studies on the erosion resistance of levees in Korea have focused mainly on improving the durability of levees against flow-induced tractive force. Since there are no standardized test procedures to assess the stability of levee protection, various methods have been suggested by researchers. For a reliable assessment, it is necessary to standardize the stability test method.

As in Korea, studies on levee erosion conducted in the rest of the world mostly revolve around levee protection, but methods that can simultaneously satisfy ecological functions are also available. In the U.S., surface treatment-based methods of levee protection have been tested in full-scale experiments under the test criteria of the American Society for Testing and Materials (ASTM).

In Japan, the Hokkaido Regional Development Bureau and the Civil Engineering Research Institute for Cold Region jointly launched a project to construct the world's largest facility devoted to various levee experiments. The size of the facility enabled the simulation of actual flood events (Figure 1). This facility is a full-scale experimental flume that can control a volumetric flow rate of $150 \mathrm{~m}^{3} / \mathrm{s}$ or 
higher using an upstream hydraulic gate operating system; it can reproduce any naturally occurring water events without relying on the scale effect. Various experimental studies have been conducted in this facility, such as improvement of the techniques to counter overflow-induced levee breach and assessment of the performance of levee protection systems [23].
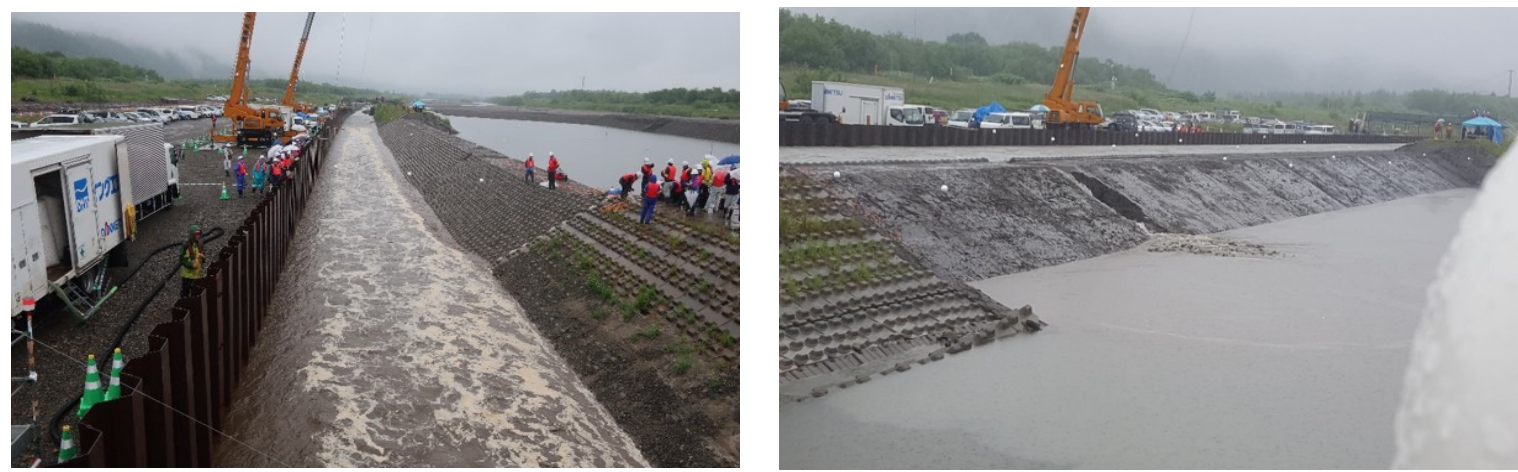

Figure 1. Levee Breach Experiment of Chiyoda Channel, Japan [23].

In the Netherlands, the Dutch Flood Protection Program (HWBP) has been initiated to complete levee reinforcement along a stretch of $1100 \mathrm{~km}$ by 2028. According to the HWBP, it aims to present an optimized solution for levee parameters such as thickness, arrangement, shape, and position through real-scale testing of the technique of reinforcing sheet pile walls embedded in levee structures (Figure 2). A levee measuring $60 \mathrm{~m}$ (length) $\times 5 \mathrm{~m}$ (height) was installed, and the levee deformation was measured in real time via various types of sensors under the experimental conditions of water seepage and application of vertical load [24].
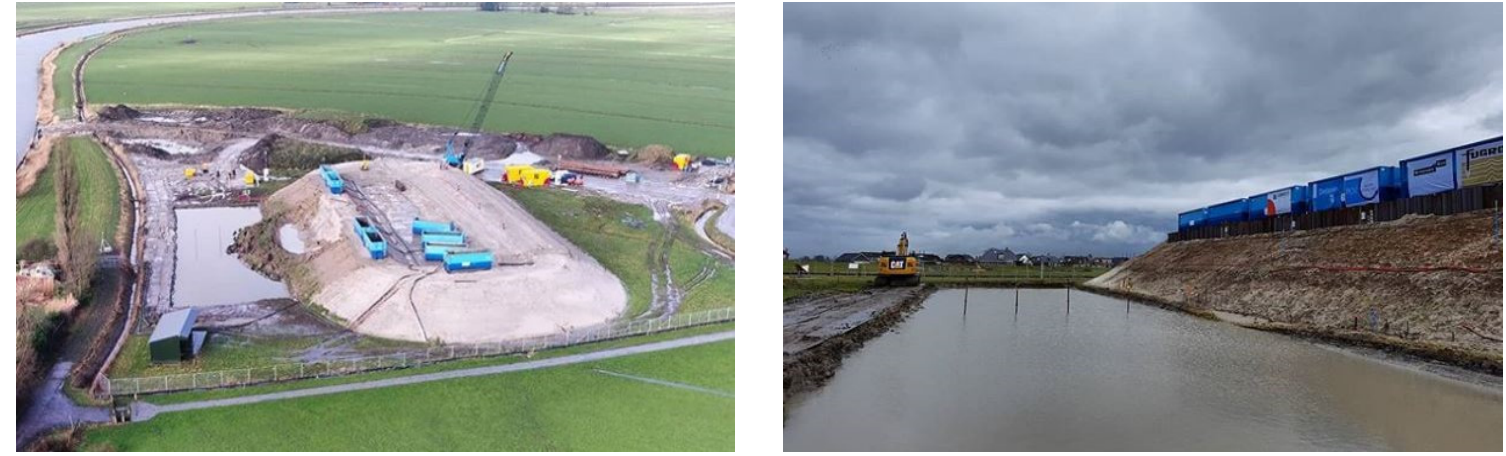

Figure 2. Levee Breach Experiment of Eemdijk, Netherlands [24].

As examined above, high-income nations have large-scale infrastructure for massive hydraulic model experiments and have performed various high-budget experiments in an effort to improve levee-related technologies. In Korea, technological developments to improve the durability of river levees have been limited to smaller experiments, mainly revetment-based erosion and scour protection. Therefore, through this study, we recommend that Korea expand its engineering infrastructure and research and development to accommodate large-scale hydraulic model experiments conducive to levee technology improvement. This will help the nation become competitive at the global level. This can be achieved only by developing new and indigenous technologies through national projects. 


\section{Description of Experiment}

\subsection{Experimental Facilies}

The Andong River Experiment Center is the only institute in Korea that has the technical expertise to evaluate the erosion resistance of levee materials through full-scale experimentation. Researchers at the organization constructed a real levee experimental laboratory (hereinafter "Levee Lab") to assess the performance and durability of a levee treated with a new material.

The Levee Lab was constructed in two stages: (1) civil foundation work for levee model construction and overflow reproduction and overall experimental safety inspection through a trial run; (2) reinforcement work in segments with safety concerns, such as flow feeder and pump inspection, reinforcement of scour zone associated with flow rate, installation of vegetation mats to reduce seepage into slope soil, reinforcement of the circulation flume for smooth drainage, and construction of access roads for heavy equipment for model production (Figure 3).
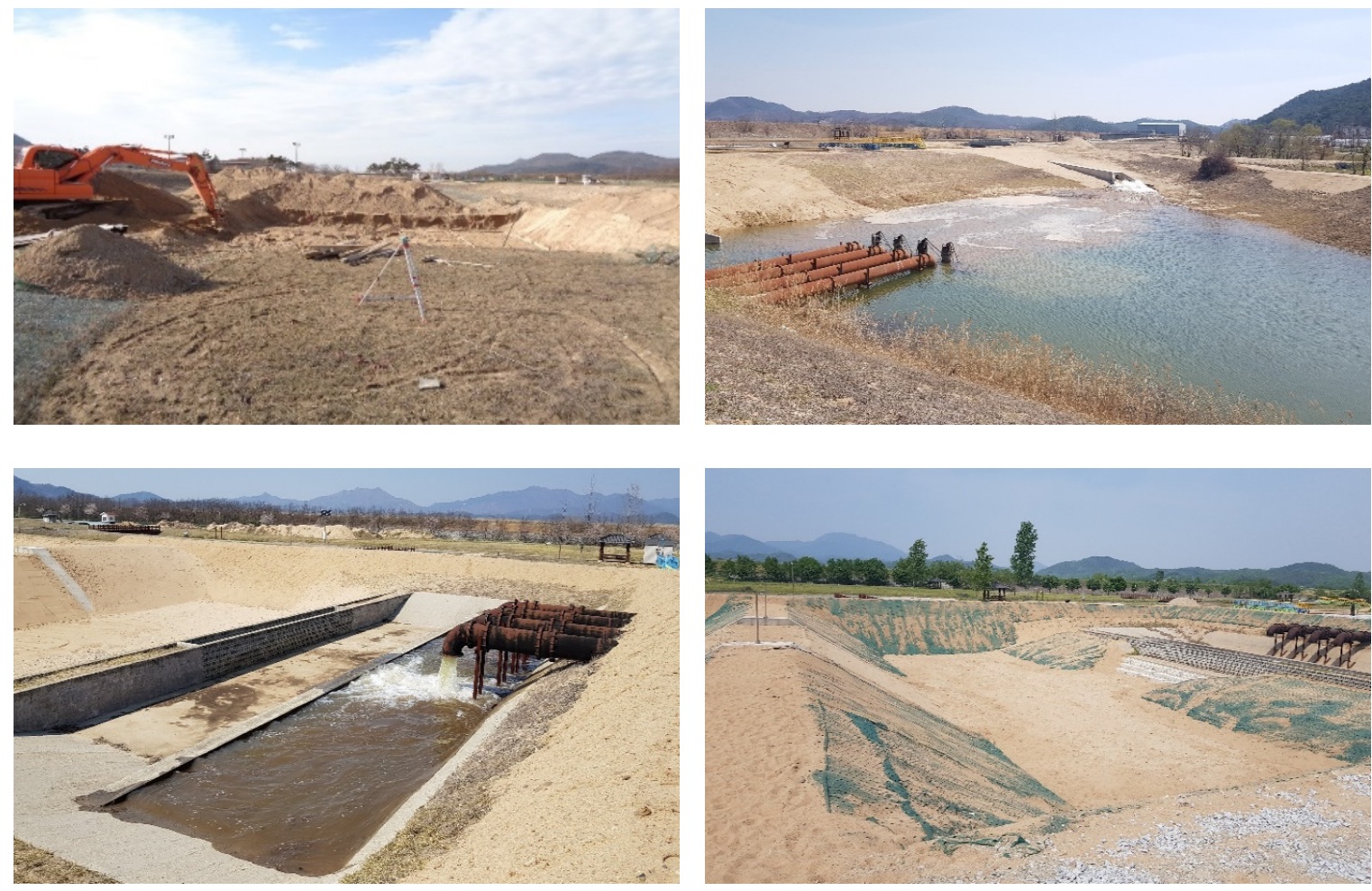

Figure 3. Construction of the Levee Lab.

Figure 4 shows the panoramic view of the completed Levee Lab. The flume is $100 \mathrm{~m}$ long (inland and river side land) and $50 \mathrm{~m}$ wide, and the upstream pump system can control volumetric flow rates of up to $2 \mathrm{~m}^{3} / \mathrm{s}$. Seepage, overflow, and piping experiments can be performed by installing a levee model up to $3 \mathrm{~m}$ high and $30 \mathrm{~m}$ wide. Additionally, by predetermining the experimental conditions (levee height, width, and supply flow rate), other experiments, such as the verification of a natural method and new concept, identification of breach mechanism, and improvement of measurement technology, can be conducted. 

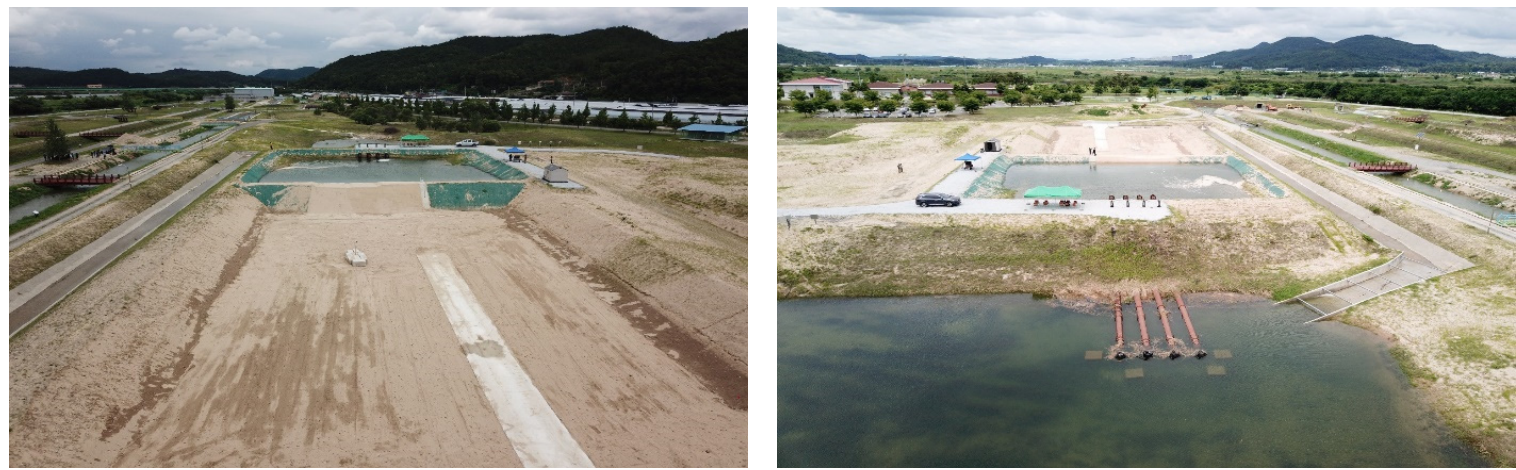

Figure 4. View of the final completed Levee Lab.

\subsection{Test Conditions}

Two overflow breach experiments were conducted to develop an optimal levee protection technology by gaining the stability of the new material levee method through verification experiments. Case 1 was a control case consisting of river sand. Case 2 was an experimental case in which a new $5 \mathrm{~cm}$ thick material layer was sprayed on the levee crown and inland side slope, and the turf was laid down. Case 1 was composed of a levee with a height of $2.7 \mathrm{~m}$, slope gradient of 1:2, overflow section of $10 \mathrm{~m}$, and total length of $14 \mathrm{~m}$. Case 2 was constructed with a height of $2.5 \mathrm{~m}$, lowered to control the overflow depth in the latter part on the assumption that the levee breach would be retarded compared with Case 1 (Figure 5). The steady-state water discharge supplied from the upstream pump station into the experimental setup was $1.0 \mathrm{~m}^{3} / \mathrm{s}$.
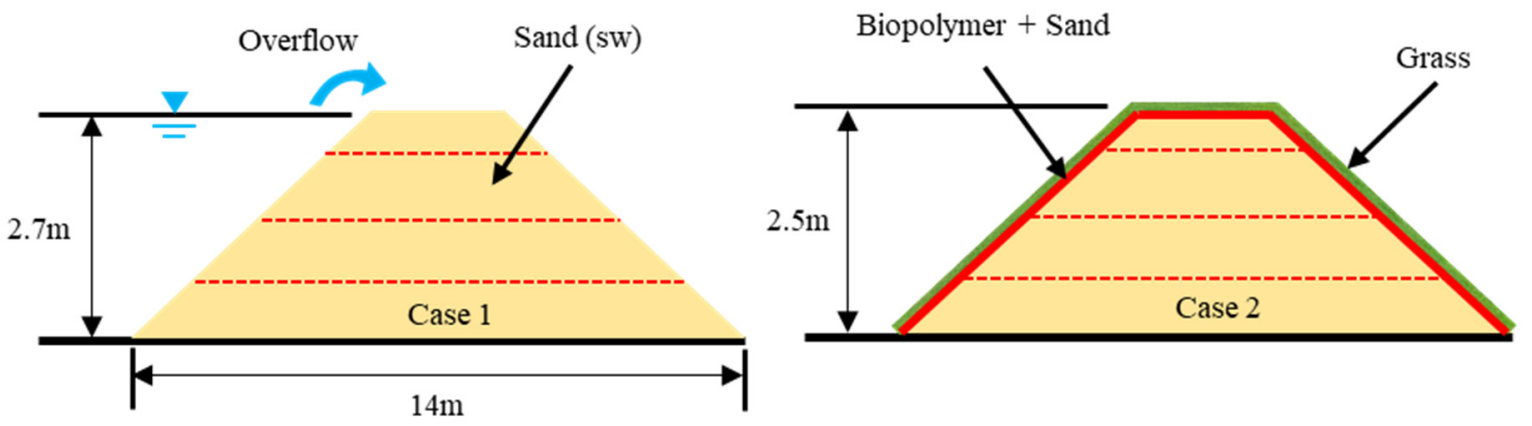

Figure 5. Experiment specifications and conditions.

We used well-graded sand (SW), which had a uniformity coefficient of 5.2 and a coefficient of curvature of 1.1, as the material for the test levee of the same condition (Figure 6). The optimal water content in the levee was $11.7 \%$, and the maximum dry density was $1.853 \mathrm{~g} / \mathrm{cm}^{3}$. The levee foundation was formed with two heavy equipment vehicles, and the compaction was performed at $50 \mathrm{~cm}$ intervals using a vibration compactor. After blending the new material according to the recipe provided by the Korea Advanced Institute of Science and Technology (KAIST), namely $1 \mathrm{~kg}$ biopolymer, $30 \mathrm{~kg}$ water, and $100 \mathrm{~kg}$ soil, the turf $(18 \times 18 \mathrm{~cm})$ was directly laid down on the blended soil. Six sprinklers were then installed to supply water for a month in order for the vegetation to take root, and the preparation for the overflow breach experiment was terminated (Figure 7). The experiment began with the overflow onset and ended with the completion of the overflow-induced levee breach. Unfortunately, as a biopolymer that has polysaccharide properties, the type of bacteria (chemical composition of the biopolymer) cannot be revealed due to copyright issues. 


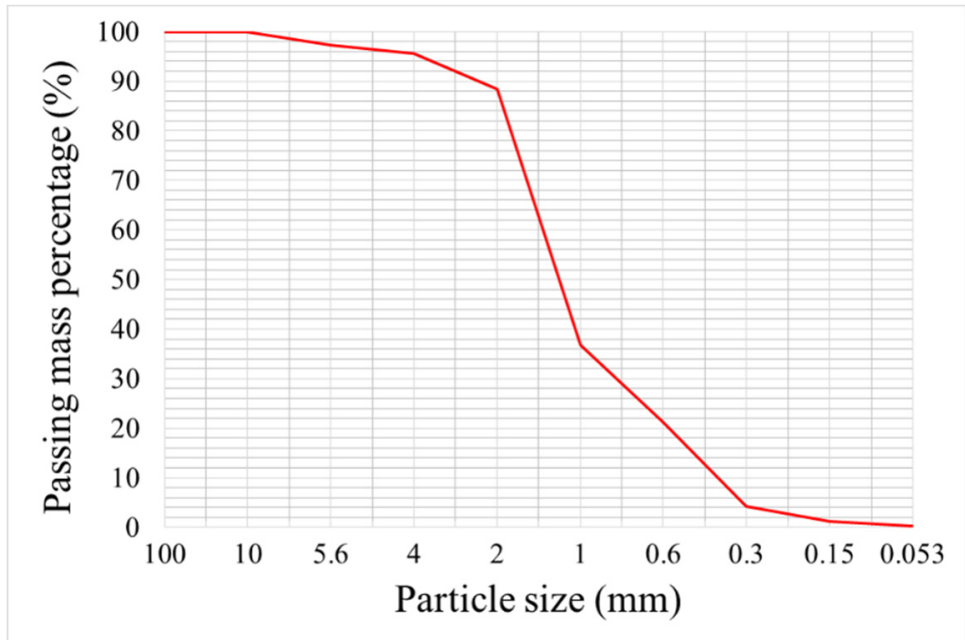

Figure 6. Grain size distribution of levee material.
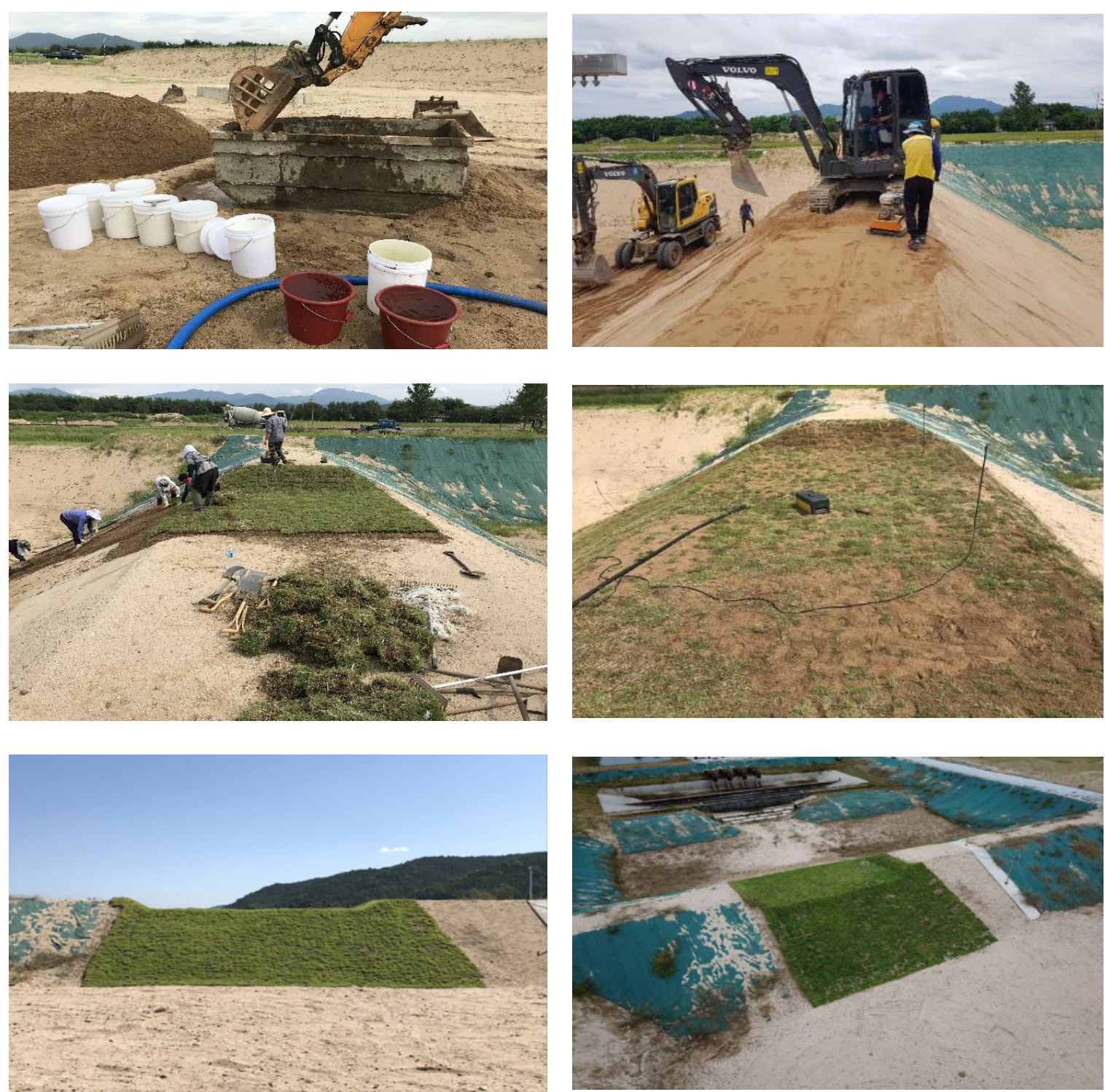

Figure 7. Construction of levee model and grass planting. 


\subsection{Measurement Method}

We installed a water level sensor (OTT Orpheus Mini water level logger, OTT Hydromet, Kempten, Germany) to record the change in water level within the flume following the levee breach. The entire process was captured in real time with multiple cameras and drones (DJI MAVIC PRO, DJI, Shenzhen, China). Given the difficulty of calculating the amount of soil discharge following the levee breach, the time-series surface loss rate was analyzed by selecting the inland-side levee slope as the quantitative analysis sample. The analysis was conducted by capturing and correcting the image every 30 s using motion graphics software (Adobe After Effects, Adobe, California, CA, USA), and data uploaded to Photoshop were subjected to digitization for the determination of the range of breach. Then, we calculated the surface loss rate by measuring the change in the number of pixels relative to the total number of pixels based on the range of breach calculated every $30 \mathrm{~s}$. By comparing the range of breach in terms of the number of pixels between the biopolymer-treated experimental model and the untreated control model, we quantitatively presented the breach-mitigating effect of the reinforcement with the new material (Figure 8).
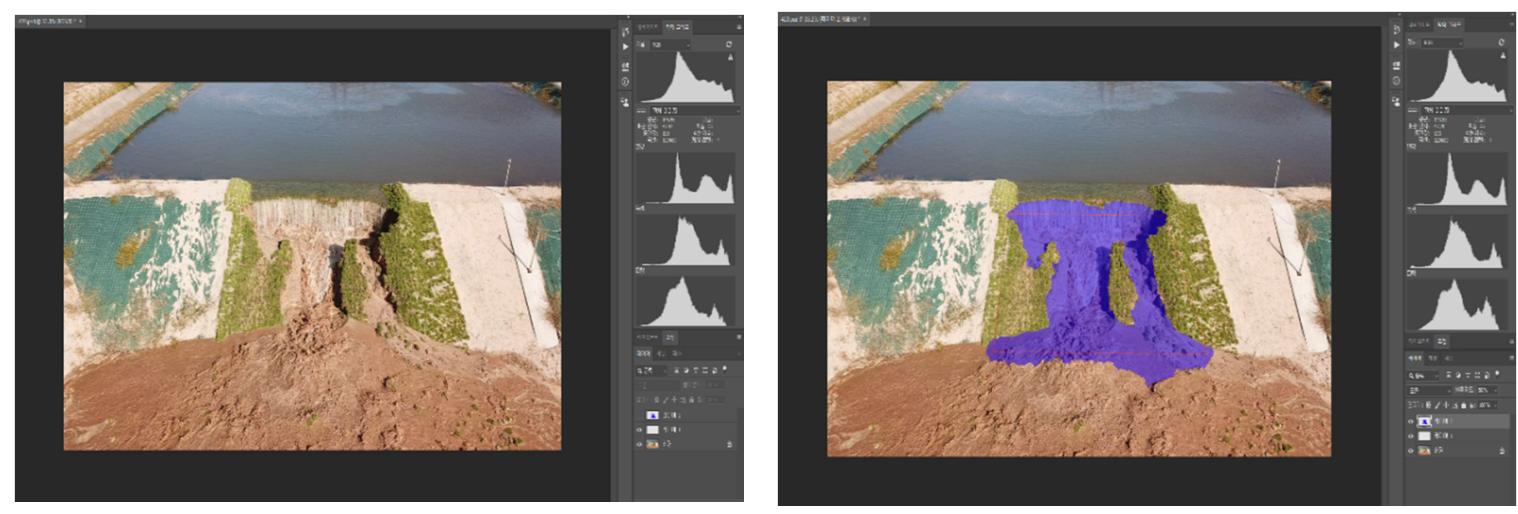

Figure 8. Image process and analysis of breach scale.

\section{Test Results}

\subsection{Water Level Observation}

Of the water level data points measured according to the experimental conditions, those within $1 \mathrm{~h}$ before and after the levee overflow onset were analyzed. Since the maximum water level and water level reduction rate varied according to levee height, comparisons were made after nondimensionalization with the water level reduction rate according to the levee height of each experimental condition.

Figure 9a shows that the water level curve steeply rose immediately after the onset of the overflow. This may be ascribed to the steady increase in the overflow depth at the early phase of the overflow until the levee crown breach. The early-phase time interval during which the water level steadily increased was longer in Case 2 than in Case 1, which implies that the development in the breach section was slower in the biopolymer-treated levee. In turn, this demonstrates the breach retardation effect of the new material reinforcement. 


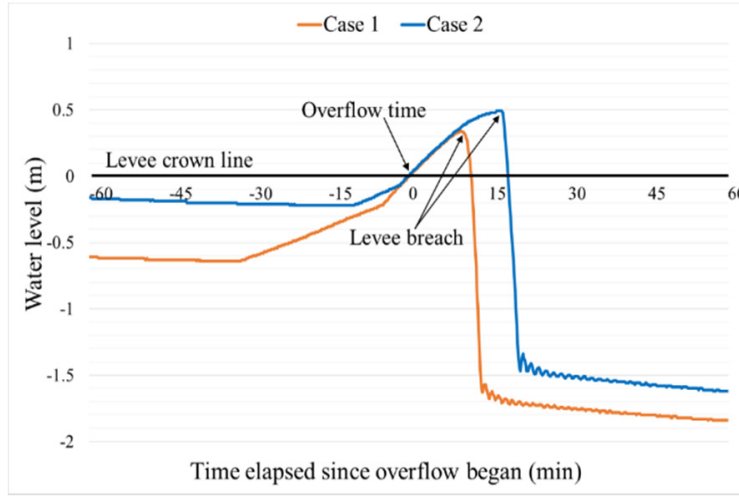

(a)

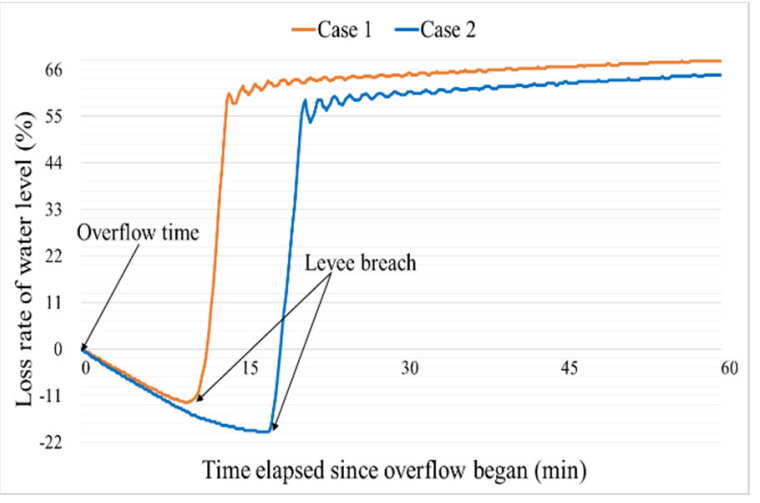

(b)

Figure 9. (a) Water level with overflow times synchronized. (b) Loss rate of water level based on levee height over time.

In Figure 9b, Case 1 exhibits the onset of the steep curve of the water level reduction rate due to levee breach $12 \mathrm{~min}$ after the onset of the overflow. Case 2 exhibits the same result after $19 \mathrm{~min}$. In addition, the maximum water level reduction rate according to the levee height in Case 2 was $64.8 \%$, which is approximately $4 \%$ lower than in Case $1(68.2 \%)$. In other words, Case 1 experienced a more drastic change in water level after the onset of the overflow than Case 2, presumably because of the increased peak outflow due to the development of the breach area. After the initial overflow, the levee was breached abruptly with the levee crown breach and concurrently with the levee slope breach.

We observed at the beginning of the experiment that there were several narrow water passages in between lumps of turf that started to slip down over the biopolymer-treated soils by sheer force of the overflow. We then observed that soil erosion followed through the narrow water channel formed by the stripped turfs. This means that the grasses did not root firmly enough to protect the surface; they were washed down by a relatively small current of overflow. In this regard, although the experimental results seem unsatisfactory, the biopolymer was found to improve erosion retardation.

\subsection{Assessment of Slope Stability through Analysis of Surface Loss Rate}

Tables 1-3 show the time-series slope loss rate of each test condition, and the analysis results are as follows. In Case 1, the breach began at the joint between the levee crown and the slope, resulting in more than $4 \%$ surface loss $30 \mathrm{~s}$ into the overflow onset. This can be seen as the stage in which an early flow pattern forms on the levee slope and develops into the main flume, causing erosion. At $120 \mathrm{~s}$ after the overflow onset, the surface loss reached 30\% and further accelerated to reach over $70 \% 240 \mathrm{~s}$ after the overflow onset. In this stage, the breach widened, causing the overflow rate to increase and consequently expedite the erosion process. A perpendicular erosion also occurred at the cross-section of the overflow. This was followed by a deep breach surface due to complete levee breach and a rapid increase in the overflow rate, and the maximum breach width was reached by the tractive force. The complete breach, with a loss rate of nearly $90 \%$, occurred at $360 \mathrm{~s}$ after the onset of the overflow with all parts of the levee destroyed, including its slopes.

Table 1. Loss area and surface loss rate over time (30-180 s).

\begin{tabular}{|c|c|c|c|c|c|c|c|}
\hline \multirow{3}{*}{ Case No. } & \multirow{3}{*}{ Area $\left(\mathrm{cm}^{2}\right)$} & \multicolumn{6}{|c|}{ Time (s) } \\
\hline & & 30 & 60 & 90 & 120 & 150 & 180 \\
\hline & & \multicolumn{6}{|c|}{ Loss Area, $\mathrm{cm}^{2}$ (Loss Rate, $\%$ ) } \\
\hline Case 1 & 670,000 & $\begin{array}{c}29,413 \\
(4.39)\end{array}$ & $\begin{array}{l}33,567 \\
(5.01)\end{array}$ & $\begin{array}{l}95,609 \\
(14.27)\end{array}$ & $\begin{array}{l}195,573 \\
(29.19)\end{array}$ & $\begin{array}{c}352,353 \\
(52.59)\end{array}$ & $\begin{array}{l}429,001 \\
(64.03)\end{array}$ \\
\hline Case 2 & 560,625 & - & - & - & $\begin{array}{l}3938 \\
(0.70)\end{array}$ & $\begin{array}{l}60,879 \\
(10.86)\end{array}$ & $\begin{array}{l}84,691 \\
(15.11)\end{array}$ \\
\hline
\end{tabular}


Table 2. Loss area and surface loss rate over time (210-360 s).

\begin{tabular}{cccccccc}
\hline & & \multicolumn{7}{c}{ Time (s) } \\
\cline { 3 - 7 } Case No. & \multirow{2}{*}{ Area $\left(\mathbf{c m}^{\mathbf{2}}\right)$} & $\mathbf{2 1 0}$ & $\mathbf{2 4 0}$ & $\mathbf{2 7 0}$ & $\mathbf{3 0 0}$ & $\mathbf{3 3 0}$ & $\mathbf{3 6 0}$ \\
\cline { 3 - 7 } & & \multicolumn{7}{c}{ Loss Area, $\mathbf{c m}^{\mathbf{2}}$ (Loss Rate, $\left.\mathbf{\%}\right)$} \\
\hline \multirow{2}{*}{ Case 1} & \multirow{2}{*}{670,000} & 454,059 & 470,742 & 506,051 & 517,508 & 545,983 & 559,852 \\
& & $(67.77)$ & $(70.26)$ & $(75.53)$ & $(77.24)$ & $(81.49)$ & $(83.56)$ \\
Case 2 & \multirow{2}{*}{560,625} & 100,764 & 158,074 & 206,858 & 242,380 & 353,174 & 362,742 \\
& & $(17.97)$ & $(28.20)$ & $(36.90)$ & $(43.23)$ & $(63.00)$ & $(64.70)$ \\
\hline
\end{tabular}

Table 3. Loss area and surface loss rate over time (390-570 s).

\begin{tabular}{|c|c|c|c|c|c|c|c|c|}
\hline \multirow{3}{*}{ Case No. } & \multirow{3}{*}{ Area $\left(\mathrm{cm}^{2}\right)$} & \multicolumn{7}{|c|}{ Time (s) } \\
\hline & & 390 & 420 & 450 & 480 & 510 & 540 & 570 \\
\hline & & \multicolumn{7}{|c|}{ Loss Area, $\mathrm{cm}^{2}$ (Loss Rate, $\%$ ) } \\
\hline Case 1 & 670,000 & $\begin{array}{c}571,376 \\
(85.28)\end{array}$ & - & - & - & - & - & - \\
\hline Case 2 & 560,625 & $\begin{array}{c}362,876 \\
(64.73)\end{array}$ & $\begin{array}{c}366,028 \\
(65.29)\end{array}$ & $\begin{array}{c}368,023 \\
(65.65)\end{array}$ & $\begin{array}{c}369,256 \\
(65.87)\end{array}$ & $\begin{array}{l}409,507 \\
(73.04)\end{array}$ & $\begin{array}{l}466,942 \\
(83.29)\end{array}$ & $\begin{array}{c}492,742 \\
(87.89)\end{array}$ \\
\hline
\end{tabular}

In Case 2, the slope loss did not occur even $100 \mathrm{~s}$ after the onset, and the levee slopes began to erode only $120 \mathrm{~s}$ after the onset. At this point, the breach area began to increase at the levee center and toes. Nevertheless, the progress of the breach was mostly retarded compared with Case 1 . The energy generated by the tractive force of the water spilling over to non-vegetated turf was transmitted to the deep soil, giving rise to the phenomenon of soil scour. This occurred only approximately $300 \mathrm{~s}$ after the onset of the overflow, in which over $50 \%$ surface loss had occurred. The time of slope breach slowly rose to $480 \mathrm{~s}$. The slope collapse developed eventually, and over $70 \%$ surface loss occurred $510 \mathrm{~s}$ after the onset. Local scour was observed at the center of the slope due to the strong vertical flow generated from the overflow resistance, causing the breach to proceed in the form of vertical erosion, which accelerated the erosion of the levee crown. At $600 \mathrm{~s}$ after the onset of the overflow, a complete breach occurred with a loss rate close to $90 \%$ (Figures 10 and 11). 

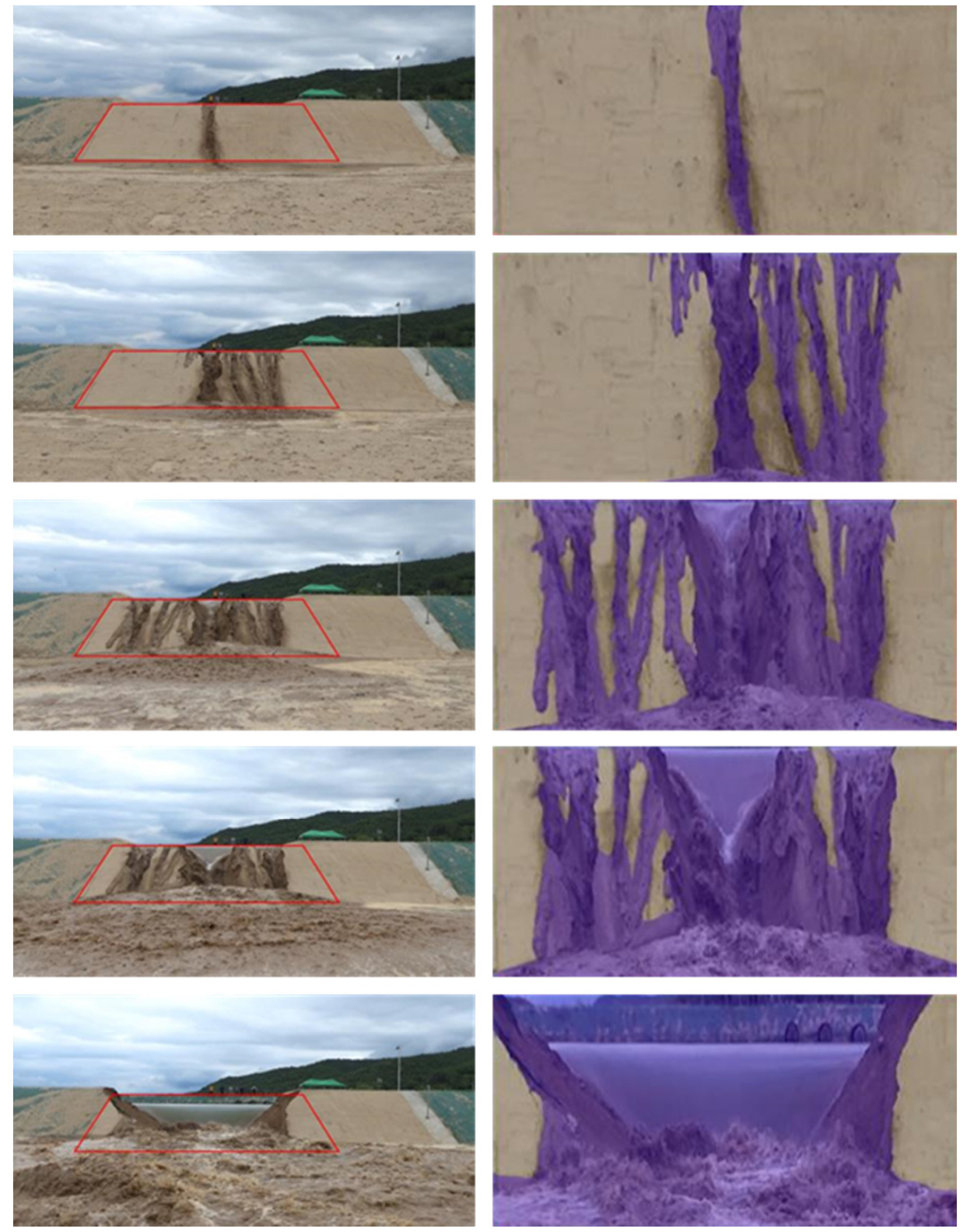

Figure 10. Time-series (1 min interval) comparison of levee slope loss rates (Case 1). 

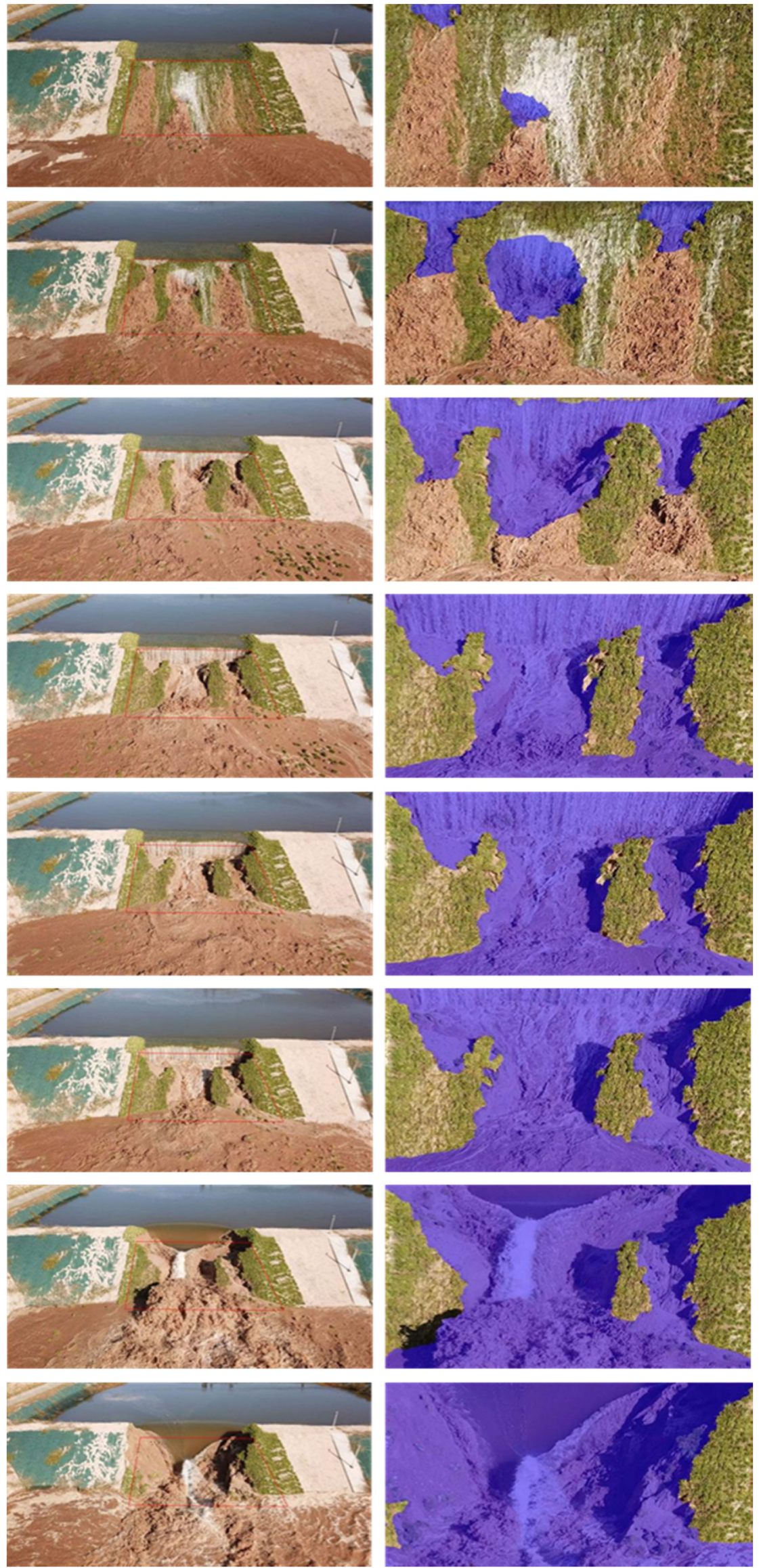

Figure 11. Time-series (1 min interval) comparison of levee slope loss rates (Case 2). 
In Case 2 (biopolymer-treated soil), since the levee crown did not erode in the early phase of the overflow, the overflow rate was significantly lower than that of Case 1 (untreated soil), even under the progressive slope breach (increasing loss rate) induced by the overflow. Figure 12 shows the time-series comparison of the levee slope loss rates between the untreated soil levee and the biopolymer-treated levee. The slope loss rate of Case 2 was retarded 1.5 to 2.3 times over time as compared to Case 1.

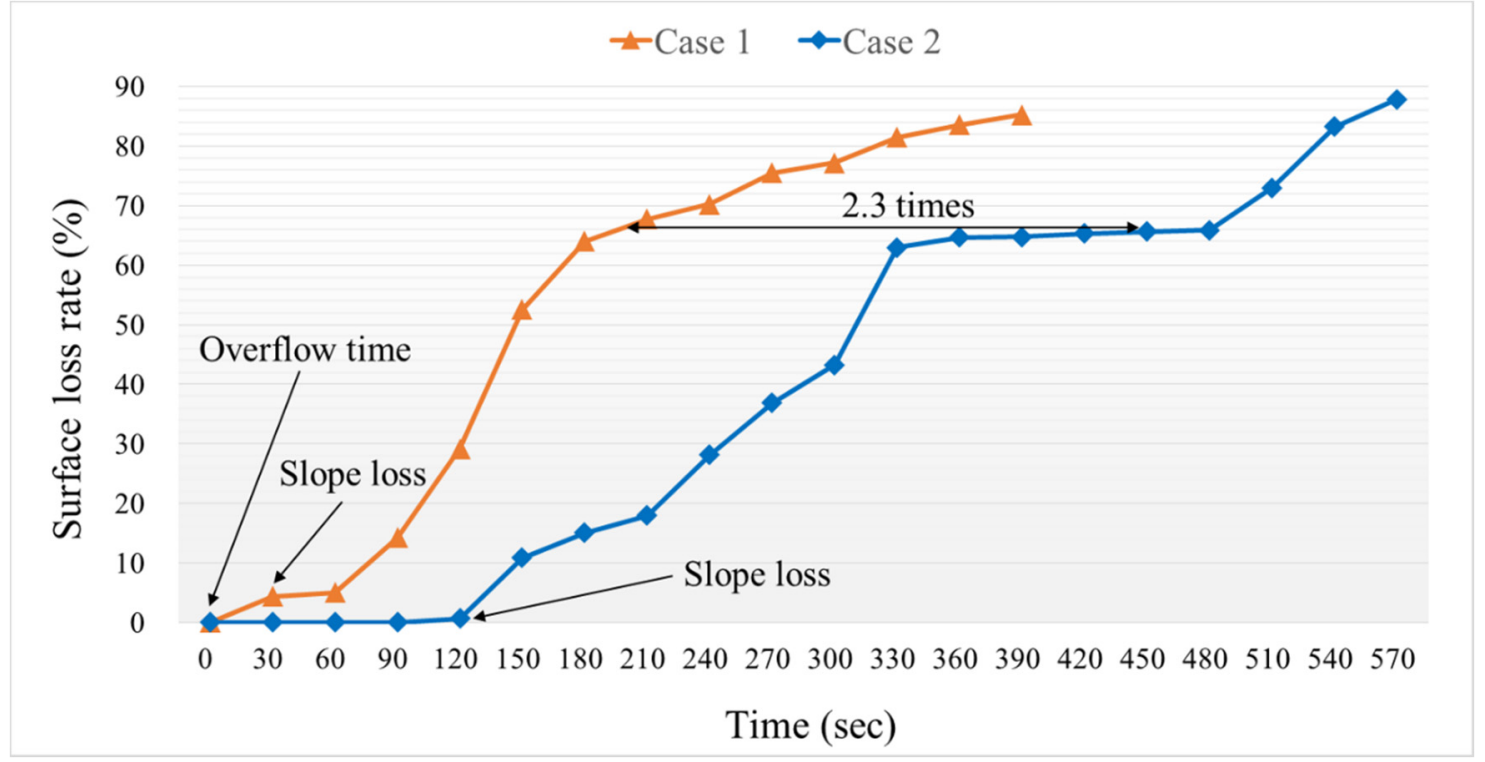

Figure 12. Comparison of surface loss rates over time in each experimental condition.

\section{Conclusions}

In this study, we constructed a full-scale levee experimental flume and conducted a full-scale overflow-induced levee breach experiment on the levee stability under two conditions: a non-reinforced sand levee condition with biopolymer-soil mixture application and a vegetation condition. The levee breach-related change in water level and the levee retardation effect of the material treatment were experimentally analyzed and presented qualitatively and quantitatively. The following conclusions were drawn:

a. The time taken for the water level to reach its minimum after the onset of the overflow in the case of the biopolymer-treated levee with grass was longer than that of the untreated one. This indicates slow development of the breach area, which in turn demonstrates the breach retardation effect of the new material reinforcement or grass. In addition, the water level changed faster in the unreinforced levee than it did in the new material-treated levee, which can be ascribed to the increase in peak discharge due to the development of the breach area.

b. A comparison of the breach retardation effect between the two types of levees revealed that in the untreated levee, the initial flow formed the main flume, which resulted in rapid and constant erosion concurrently with the levee crown breach. In the treated levee, the initial erosion did not occur, and the continuous overflow led to a discontinuous erosion at the levee center and toes, demonstrating entirely different breach mechanisms. On a related note, the time-series slope loss rate in the reinforced levee was 1.5-2.3 times less that it was in the unreinforced levee, improving flood control stability, which in turn prolongs the evacuation time in the event of a flood given that the levee breach directly results in a rapid increase in flood flow.

The erosion resistance of the new biopolymer-treated levee was only 50\% higher than that of the unreinforced levee. This may be explained by the fact that the roots were not properly developed because of the unfavorable environment (above all, weather) at the time of levee production. This points to the limitation of a single quantitative assessment, i.e., a one-off comparison of the breach retardation 
effect between experimental and control groups is not enough to generalize a levee's performance. Therefore, more experiments must be conducted with different compositions and concentrations of the biopolymer regardless of the levee vegetation. It is also necessary to use a spraying method that has the advantage of workability when applying a new material to the levee slope [25].

There is difficulty associated with taking onsite measurements in a full-scale experimental setup. Several different attempts were made, including large-scale particle image velocimetry (LSPIV), pore water pressure (PWP), and fiber-optic sensing, but no satisfactory data could be obtained due to weather effects and sensor losses.

In follow-up studies, these limitations must be addressed, and reasonable outcomes applicable to the evaluation of the stability of the new material-treated levee must be derived by obtaining the mean values of measurement data and breach retardation time. Hopefully, we will establish an advanced testing method through a continuous verification experiment that may become a leading global levee technology.

Author Contributions: D.K. and J.K. designed the experiment concept; D.K. carried out the experiments and wrote the original draft; J.K. reviewed and edited the draft. All authors have read and agreed to the published version of the manuscript.

Funding: This research was supported by a grant (20AWMP-B114119-05) from the Advanced Water Management Research Program (AWMP) funded by the Ministry of Land, Infrastructure and Transport of the Korean government.

Conflicts of Interest: The authors declare no conflict of interest.

\section{References}

1. Woo, B.M. Vegetation influences on the slope stabilization. J. Korean Soc. For. Sci. 1977, 35, 47-55. (In Korean)

2. Lee, C.K.; Bae, W.S.; Kim, S.S.; Han, J.H. A case study on vegetation system applied on cutting slope. J. Korean Geo-Environ. Soc. 2005, 6, 21-30. (In Korean)

3. Ji, U.; Jang, E.K.; Ahn, M.H.; Kim, W. Development and verification of eco-hybrid rolling mat for preventing bank erosion based on large-scale experiments. Ecol. Resilient Infrastruct. 2019, 6, 217-226. (In Korean)

4. Woo, H.S. Levee technologies based on nature, Korean society of civil engineers (Magazine). Technology Article. 2019, 67, 36-41. (In Korean)

5. Chinnarasri, C.; Jirakitlerd, S.; Wongwises, S. Embankment dam breach and its outflow characteristics. J. Civ. Eng. Environ. Syst. 2004, 21, 247-264. [CrossRef]

6. Hanson, G.J.; Cook, K.R.; Hunt, S.L. Physical modeling of overtopping erosion and breach formation of cohesive embankments. Am. Soc. Agric. Eng. 2005, 48, 1783-1794. [CrossRef]

7. Chi, B.H.; Kim, K.M.; Kim, J.M.; Lee, D.Y. Seepage characteristics of domestic bed sediments mixed with good-quality soil as levee fill material. J. Korean Geotech. Soc. 2008, 24, 105-111. (In Korean)

8. Zhang, J.; Li, Y.; Xuan, G.; Wang, X.; Li, J. Overtopping breaching of cohesive homogeneous earth dam with different cohesive strength. Sci. China Ser. E: Technol. Sci. 2009, 52, 3024-3029. [CrossRef]

9. Pickert, G.; Weitbrecht, V.; Bieberstein, A. Breaching of overtopped river embankments controlled by apparent cohesion. J. Hydraul. Res. 2011, 49, 143-156. [CrossRef]

10. Schmocker, L.; Hager, W.H. Plane dike-breach due to overtopping: Effects of sediment, dike height and discharge. J. Hydraul. Res. 2011, 50, 576-586. [CrossRef]

11. Orendorff, B.; AI-Riffai, M.; Nistor, L.; Rennie, C.D. Breach outflow characteristics of non-cohesive embankment dams subject to blast. Can. J. Civ. Eng. 2013, 40, 243-253. [CrossRef]

12. Jin, J.H.; Lee, T.H.; Yoo, J.Y.; Im, E.S.; Lee, S.J.; Kim, Y.S. An experimental study on overflow and internal erosion protection technology of a reservoir. J. Korean Geosynth. Soc. 2019, 18, 181-191. (In Korean)

13. Schmocker, L. The failure of embankment dams due to overtopping. J. Hydraul. Res. 2009, 47, 288. [CrossRef]

14. Shimada, T.; Yokoyama, H.; Hirai, Y.; Miyake, H. Experiment for the destructive mechanism of the overflow levee and flooding area at the chiyoda experimental channel. J. Japan Soc. Civ. Eng. Ser. B1 (Hydraul. Eng.) 2011, 67, 841-846. (In Japanese) [CrossRef]

15. Park, M.C.; Lee, J.W.; Kim, Y.S.; Han, H.S. Seepage analysis of large-scale embankment model by revised tdr sensor. J. Korea Geotech. Soc. 2012, 28, 53-67. (In Korean) 
16. Kim, J.M.; Park, M.C.; Jo, W.B.; Han, H.S. Seepage analysis of weathered granite model embankment using tdr sensor. J. Korean Geotech. Soc. 2014, 30, 17-28. (In Korean) [CrossRef]

17. Joo, Y.H.; Yeo, C.G.; Lee, S.O. Retardation effect on the breach of the earth filled embankment using the stiffener during overtopping. J. Korean Soc. Civ. Eng. 2013, 33, 1377-1387. (In Korean) [CrossRef]

18. Ko, D.W.; Kang, J.G. Experimental studies on the stability assessment of a levee using reinforced soil based on a biopolymer. Water 2018, 10, 1059. [CrossRef]

19. Chang, I.H.; Im, J.Y.; Prasidhi, A.K.; Cho, G.C. Effects of Xanthan gum biopolymer on soil strengthening. Constr. Build. Mater. 2015, 74, 65-72. [CrossRef]

20. Chang, I.H.; Im, J.Y.; Cho, G.C. Introduction of microbial biopolymers in soil treatment for future environmentally-friendly and sustainable geotechnical engineering. Sustainability 2016, 8, 251. [CrossRef]

21. Chang, I.H.; Im, J.Y.; Lee, S.W.; Cho, G.C. Strength durability of gellan gum biopolymer-treated Korean sand with cyclic wetting and drying. Constr. Build. Mater. 2017, 143, 210-221. [CrossRef]

22. An, J.H.; Jeong, H.S.; Kim, E.S. Effects of the $\beta$-glucan- and xanthan gum-based biopolymer on the performance of plants inhabiting in the riverbank. Ecol. Resilient Infrastruct. 2018, 5, 180-188. (In Korean)

23. Kakinuma, T.; Shimizu, Y. Large-scale experiment and numerical modeling of a riverine levee breach. J. Hydraul. Eng. 2014, 140, 04014039. [CrossRef]

24. Breedeveld, J.; Zwanenburg, C.; Van, M.; Lengkeek, H.J. Impact of the Eemdijk full-scale test programme. In Proceedings of the XVII European Conference on Soil Mechanics and Geotechnical Engineering, Reykjavik, Iceland, 1-6 September 2019; pp. 1-8.

25. Seo, S.H.; Jin, S.N.; Chang, I.H.; Chung, M.K. The analysis of effect of biopolymer treated soils in seed spray method in the river embankment. Ecol. Resilient Infrastruct. 2019, 6, 304-313. (In Korean)

(C) 2020 by the authors. Licensee MDPI, Basel, Switzerland. This article is an open access article distributed under the terms and conditions of the Creative Commons Attribution (CC BY) license (http://creativecommons.org/licenses/by/4.0/). 